\title{
8 ENGAGING YOUTHS VIA E-PARTICIPATION INITIATIVES: An Investigation into the Context of Online Policy Discussion Forums
}

\author{
Chee Wei Phang \\ Atreyi Kankanhalli \\ National University of Singapore \\ Singapore
}

\begin{abstract}
Advances in information and communication technologies (ICTS) have offered governments new opportunities to enhance citizen participation in democratic processes. The participation opportunities afforded by ICT may be particularly pertinent for youths, who are more likely to be ICT-savvy and yet are reported to show declining participation in politics. The currently increasing exclusion of youths from democratic processes has been attributed to their apathy toward politics and a lack of participation channels for them. ICT as a familiar tool for this specific age group may present an opportumity to elicit youths' participation in democratic processes. In this study we examine an e-participation initiative targeted at youths and seek to investigate the factors contributing to their participation in an online discussion forum employed for policy deliberation. We build upon theoretical bases from the political science and information systems literature to construct a research model of participation in online policy discussion forums. As an initial study of youths' e-participation, our survey indicates that collective and selective incentives may positively impact youths' participation intention. In addition, civic skills and political efficacy of individuals may also contribute to their participation. Connectivity with an online policy discussion forum can enhance youths' perceptions of selective process incentives while communality negatively impacts their intention to participate. Overall, our study aims to inform theory by showing that existing participation theories may be applicable to youth's participation in the electronic context. Further, ICT features (connectivity and communality) are found to have both positive and negative effects on participation. The findings may provide insights to practitioners for promoting inclusion of youths in democratic processes via e-participation initiatives.
\end{abstract}

Please use the following format when citing this chapter:

Phang, C.W., and Kankanhalli, A., 2006, in IFIP International Federation for Information Processing, Volume 208, Social Inclusion: Societal and Organizational Implications for Information Systems, eds. Trauth, E., Howcroft, D., Butler, T., Fitzgerald, B., DeGross, J., (Boston: Springer), pp. 105-121. 
Keywords

E-Participation, inclusion of youths, online policy discussion forum, participation theories, ICT features

\section{INTRODUCTION}

Governments around the world are tapping into the potential of information and communication technologies (ICT) to enable citizen participation in democratic processes (e.g., Whyte and Macintosh 2002). It is argued that enhanced citizen participation can lead to formulation of policies that are more realistically grounded in citizens' preferences and improved public support for these policies (Aristotle 1987; Irvin and Stansbury 2004). Implementation of citizen participation programs can be traced back as far as 1950s (Day 1997), with the first deployment of ICT to enable participation about two decades later (Hiltz and Turoff 1978). Today e-participation initiatives are exploiting the Internet's capabilities of providing $24 / 7$ accessibility as well as mass transmission and reception of information to facilitate citizen participation.

The use of ICT to enable participation may be particularly relevant to youths. It is seen that youths' participation in politics has been generally declining over the years (e.g., Institute of Politics 2002). Some studies attribute this to youths' apathy toward politics (Bennett 1997). Others find that despite youths' purported interest in political issues, they lack appropriate channels to participate (Institute of Politics 2002). Such a trend suggests a widening exclusion or disengagement of youths from democratic processes. This is troubling because youths are a nation's most valuable future asset. Ensuring the inclusion of youths in democratic processes is important in preparing them to exercise their rights and responsibilities of citizenship and increase their involvement in the future governance of the country. Being a generation that has grown up with ICT, youths today have been found to be more technology savvy (Pew Research 2000) and more ready to embrace new e-Government applications (Thrane et al. 2004) than other age groups. Given that youths are regular users of ICT in their everyday life, they may find the use of ICT for participation appealing. Hence, to policy makers, ICT may present an opportunity to combat the trend and promote inclusion of youths in democratic processes.

While ICT is increasingly being deployed to enable participation, little is known of the factors responsible for e-participation. To address this void, we delve into political science and information systems literatures to identify antecedents of citizen participation, particularly in the context of online discussion forums. The online discussion forum is deemed a low cost, scalable ICT that is particularly suited for policy deliberation (Kumar and Vragov 2005). In this study we use the term online policy discussion forum (henceforth denoted by OPDF) to refer to Web-based forums using bulletin boards employed by governments to engage citizens in policy deliberation. The integration of the relevant participation factors and ICT features form our research model, which is empirically tested through a survey of youths' intention to participate in an OPDF. 


\section{CONCEPTUAL BACKGROUND AND RESEARCH MODEL}

In the political science literature, two widely employed theoretical perspectives that elucidate individual-level participation factors are socio-economic theories and rational choice theories. We describe two specific participation models that are derived from these two theoretical strands: civic voluntarism model (Verba et al. 1995) and general incentives model (Seyd and Whiteley 1992). In addition we also identify two ICT features that are likely to be relevant in the context of e-participation via OPDF.

\subsection{Socio-Economic Theories and Civic Voluntarism Model}

Socio-economic theories attempt to explain citizen participation in terms of the social circumstances that shape an individual's attitude toward participation (Parry et al. 1992; Verba and Nie 1972). Social circumstances include an individual's age, education level, and financial status. While initial thinking along this perspective held that individuals who are older, better educated, and wealthier are more likely to participate, subsequent research questioned such propositions and the mechanisms behind the effects of socio-economic factors (Verba et al. 1995). Past studies have also shown that the general rise in education level does not necessarily lead to increased electoral participation (e.g., Lyons and Alexander 2000). These limitations have led to refinements in socio-economic theories in terms of including a more comprehensive set of participation factors and the mechanisms linking social circumstances to participation.

Along this line, Verba et al. (1995) developed the civic voluntarism model (CVM), which aims to specify "in detail how socio-economic position is linked to political activity" (p. 19). Cited as the most widely employed participation theory (Seyd et al. 2001), the model considers resources, motivations, and mobilization as antecedents of participation. Resources that include time, money, and civic skills (individual's organizational and communications abilities that can facilitate their political participation) bridge the individual's socio-economic status to their participation. In other words, individuals with better socio-economic status are more likely to participate because they possess the resources to do so. Motivations are conceptualized as individual and group incentives as well as a sense of political efficacy (Verba et al. 1995). Political efficacy refers to the individual's perception that political change is possible, and that the individual citizen can play a part in bringing about this change (Campbell et al. 1954). Last, mobilization refers to the extent to which individuals are influenced by people around them to participate.

\subsection{Rational Choice Theories and General Incentives Model}

Rational choice theories of participation see citizen participation as a rational activity in which the aim is to maximize benefits and minimize costs (Olson 1965). In 
this light, the individual's decision to participate is essentially an outcome of costbenefit calculation. The perceived benefits from participation are closely tied to one's political efficacy. However, rational choice theories have been criticized for not being able to explain electoral participation. In an election where many actors are involved, the likely influence that an individual has on the outcome, and thus the potential benefit, is extremely small. Considering the cost required to vote, a truly rational actor may choose not to vote. However, we do see people participating in elections. Explanations have been offered in terms of the sufficiently low cost of voting (Aldrich 1993) and in subsequent refinements to the initial theories.

Arguing that the benefits for participation are too narrowly conceptualized in traditional rational choice theories, Seyd and Whiteley (1992) developed a general incentives model (GIM) that incorporates incentives related to altruistic concerns and social norms. The resulting GIM encompasses five incentives types for participation: collective, selective, group, expressive, and social norms-derived incentives. Collective incentives are derived from policy goals that are available for all to enjoy regardless of whether one participates (e.g., tax reduction). This is in contrast to selective incentives that are restricted to participants, which include the gratification obtained during the participating process (e.g., enjoying interaction with others) and the privatized outcomes from participation (e.g., political career advancement). Group incentives and expressive incentives are related to individuals' attachment to a group (e.g., political party). Group incentives have to do with individuals' perception about the efficacy of the group as a whole to bring about desired social change, whereas expressive incentives are grounded in a sense of loyalty and affection to the group. Finally, social norms-derived incentives refer to the influence of other people on the individual's willingness to participate, and are similar to the concept of mobilization in the CVM.

\subsection{Antecedents of Participation Derived from the Two Models}

Based on the above discussion, we integrate the resource and mobilization concepts from the CVM with the incentives from the GIM to develop our model of eparticipation. The five incentive types explicated in the GIM may serve as motivations of participation outlined in the CVM. Of the five incentives, we consider collective and selective incentives of particular relevance. Group and expressive incentives are less relevant in the context of the general population where individuals may not be members of political organizations, that is, the two incentive types assume citizens' attachment to a group (e.g., political party). Social norms-derived incentives are captured through the concept of mobilization in CVM.

Collective incentives in the context of participation in OPDF refer to the benefits that are available for all to enjoy whether or not they participate in the OPDF. These incentives can be in the form of improved policies resulting from participation by some individuals in the OPDF, but which will benefit all including nonparticipants (Seyd and Whiteley 1992). Although collective incentives are subject to the "free-rider" problem (Olson 1965), such incentives remain important because people realize that they would not materialize if everyone chooses to stay inactive (Gamson 1975). Consistent with 
this logic, past studies have shown significant effect of collective incentives on participation (e.g., Scholzman et al. 1995). Therefore, we expect that

\section{H1: Collective incentives are positively related to intention to participate in $O P D F$.}

Selective incentives include selective process incentives derived from the process of participating in the OPDF, such as the enjoyment in interacting with others (Seyd and Whiteley 1992). These incentives are found to be salient for participation that involves participant interactions (Scholzman et al. 1995), such as during the policy deliberation process in OPDF. Selective incentives also include selective outcome incentives, defined as privatized outcomes accruing from participating in the OPDF. These incentives can be in the form of furthering one's political career (e.g., becoming a community leader) (Seyd and Whiteley 1992) and fulfillment of civic duties (Verba et al. 1995). To the extent that these privatized outcomes are attractive to an individual, his or her intention to participate is expected to be higher.

H2: Selective process incentives are positively related to intention to participate in $O P D F$.

H3: Selective outcome incentives are positively related to intention to participate in $O P D F$.

Political efficacy (Verba et al. 1995) is expected to be another important motivational factor for participation intention in OPDF. The positive relationship between political efficacy and participation is well documented in the literature (Brady et al. 1995; Rosenstone and Hansen 1993). Previous studies have identified two dimensions of political efficacy, internal and external (Niemi et al. 1991). Internal political efficacy refers to the beliefs about one's own competence to understand and to participate effectively in politics, whereas external political efficacy refers to individual's beliefs about the responsiveness of government authorities to citizen demands (Niemi et al. 1991). The more individuals feel that they are politically competent and that government will respond to their inputs, the higher their intention would be to participate in OPDF.

\section{H4: $\quad$ Political efficacy is positively related to intention to participate in $O P D F$.}

In addition to motivations, the CVM emphasizes the role of resource factors in determining an individual's participation. Since participating in OPDF requires formulation and expression of ideas, a salient resource factor may be the civic skills (Brady et al. 1995; Verba et al. 1995). Individuals who possess the requisite organizational and communications capacities, who can speak or write well and feel comfortable taking part in discussions, will find it less daunting to participate in policy deliberation through the OPDF. This will likely translate into their higher intention to participate in the OPDF.

H5: Civic skills are positively related to intention to participate in $O P D F$. 
Last, mobilization is also expected to influence participation in OPDF. Mobilization can be seen as a product of social norms, which are pressures to conform to the influence of other people (Whiteley 1995). Mobilization for participation in the OPDF may be in the form of requests that come to individuals from their friends, relatives, acquaintances, or strangers. Being asked to participate by others has been found to be a triggering factor for participation (Rosenstone and Hansen 1993). Therefore we expect that

H6: Mobilization is positively related to intention to participate in OPDF.

\subsection{ICT Features Pertinent to Participation in OPDF}

A number of ICT features have been highlighted with respect to communication and other tasks. However, in the context of e-participation via OPDF, we are concerned with those features of ICT that enhance collective action such as policy deliberation and formulation. Previous literature indicates connectivity and communality as two features of ICT that are relevant in the context of collective action (Fulk et al. 1996).

Connectivity is the feature of ICT that enables individuals who share common goals and interests to easily communicate with each other (Fulk et al. 1996; Kumar and Benbasat 2001). Monge et al. (1998) observe that the connectivity offered by interorganizational information systems can create benefits of easy collaboration and coordination between members. In an OPDF, messages are structured and displayed according to topic along with the message posters. This allows individuals to easily identify others who share similar interests and goals, and communicate with them by directly replying to their postings. Such connectivity afforded by the OPDF may help amplify the selective process incentives obtainable from participation. If individuals are able to easily reach and communicate with others who share common goals and interests, they are likely to perceive greater enjoyment from such interactions during participation. Connectivity is also expected to have a direct positive impact on participation intention as the feature can facilitate collective deliberation on a policy issue through the OPDF (Kumar and Vragov 2005).

H7a: Connectivity is positively related to selective process incentives obtainable by participating in $O P D F$.

\section{H7b: Connectivity is positively related to intention to participate in OPDF.}

Communality refers to the availability of a commonly accessible pool of information enabled by ICT to all participants (Fulk et al. 1996; Monge et al. 1998), such as through the OPDF. The fundamental function of communality is to facilitate generalized and productive types of exchange (Cook 1991). Generalized exchange refers to a pattern of social exchange where an individual may contribute to and receive resources from different people. In productive exchange, information is assembled and analyzed to create something new, such as formulation of broad public policy from data gathered (Fulk et al. 1996). The OPDF may serve as a repository containing relevant policy information contributed by policy makers and other participants. Such communality afforded by the OPDF may reduce the cost of a participant's access to a common pool 


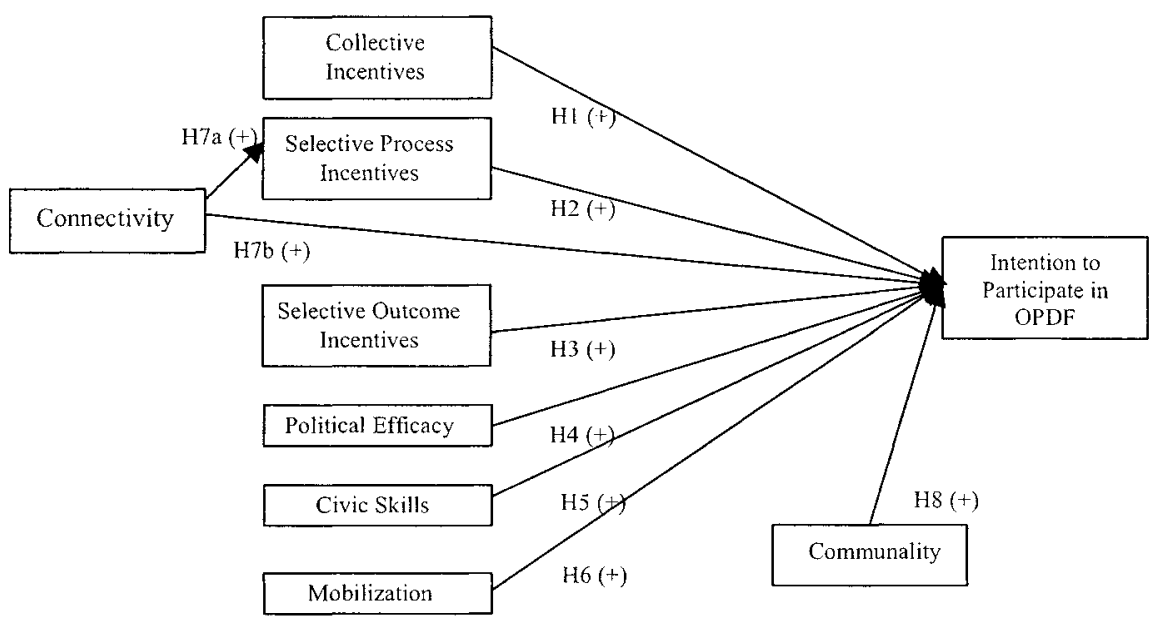

Figure 1. Research Model of Participation in Online Policy Discussion Forum

of relevant policy information (Kumar and Vragov 2005) and make exchange of information easier, thus facilitating participation in policy deliberation. Therefore, we expect that the communality feature would promote intention to participate.

H8: Communality is positively related to intention to participate in $O P D F$.

The above hypotheses constitute our research model shown in Figure 1.

\section{RESEARCH METHODOLOGY}

The survey method was employed in this study to aim for better generalizability of results. Given that the study was exploratory and some items were self-developed, a thorough instrument validation exercise was conducted as per procedures prescribed by Moore and Benbasat (1991).

\subsection{Construct Operationalization}

Where available, constructs were measured using tested items from previous literature to enhance validity. Other items were developed by converting the definition of constructs into questionnaire format. ${ }^{1}$

\footnotetext{
${ }^{1}$ The questionnaire items are available upon request from the authors.
} 
All constructs were modeled as reflective constructs, except selective outcome incentives, political efficacy, and civic skills. Selective outcome incentives are modeled as a formative construct consisting of two dimensions: fulfillment of civic duty and political career advancement (Seyd and Whiteley 1992; Verba et al. 1995). Political efficacy is measured as a formative construct with two dimensions: internal political efficacy and external political efficacy (Niemi et al. 1991). Civic skills are modeled as a second-order formative construct in which individuals' practicing of five relevant skillacts adapted from Brady et al. (1995) and Verba et al. (1995) in three places where these skill-acts are commonly practiced (i.e., workplace, voluntary organizations, and religious institutions) are measured. Last, mobilization is a single-item measure in which respondents were asked whether they have been requested by people surroudning them to participat ein the OPDF (Verba et al. 1995).

\subsection{Context of Study and Survey Administration}

The study was conducted in Singapore, which is ranked second for e-participation readiness (UPAN 2005). In conjunction with the Singapore government's growing emphasis on engaging citizens, public consultation was made a requirement for formulation of all government policies starting in 2004 (Chia 2004). A government consultation portal (http://www.feedback.gov.sg) has been launched to solicit citizens' inputs on a range of policy issues. One of the goals of this portal is engage youths, who are observed to be increasingly apathetic about politics (Vinluan et al. 2005). The target eparticipation initiative in our study represents one such effort to promote inclusion of youths in consultation through the portal. The initiative invites inputs from youths on the building and designing of a youth community space in the downtown area of Singapore via an OPDF.

We administered the survey to Singaporean undergraduate students across various disciplines at a large public university. Undergraduate students have been typically used as a representative sample in previous studies of youths' involvement (Institute of Politics 2002; Jarvis et al. 2005). The survey was administered after the lecture session of four higher-level undergraduate courses. All students of Singaporean nationality took the survey, amounting to 126 responses received. Participation in the survey was voluntary. Nonetheless, a token payment was given for their participation. Respondents were first directed to the target OPDF before they filled in the survey form. Since only a handful of students had visited the consultation portal before, intention to participate was considered as a suitable dependent variable as compared to actual participation. Respondents were asked to provide their responses with respect to the above-mentioned e-participation initiative. Of the 126 responses received, 5 were dropped due to substantial missing data. This resulted in a total of 121 usable responses for data analysis. Demographic information of our respondents is shown in Table 1.

\subsection{Data Analysis and Results}

Partial least square (PLS) was used for data analysis due to the formative constructs (selective outcome incentives, political efficacy, and civic skills) in our model. Additionally, PLS can be used for prediction-oriented studies and is appropriate for early 
Table 1. Demographic Information of Respondents

\begin{tabular}{|l|c|c|c|}
\hline \multirow{2}{*}{ Gender } & Category & $\begin{array}{c}\text { Frequency } \\
(\mathbf{n = 1 2 1})\end{array}$ & Percent \\
\hline \multirow{3}{*}{ Age } & Male & 81 & $67 \%$ \\
\cline { 2 - 4 } & Female & 40 & $33 \%$ \\
\hline Computer Experience & $19-21$ & 28 & $23 \%$ \\
\cline { 2 - 4 } & $22-24$ & 85 & $70 \%$ \\
\cline { 2 - 4 } & $25-27$ & 8 & $7 \%$ \\
\hline Internet Experience & Mean $=9.93$ years; Standard Deviation $=2.73$ \\
\hline
\end{tabular}

stages of theory development (Fornell 1982). Given that this study represents an initial attempt to explore factors influencing intention to participate in OPDF, PLS was deemed appropriate. PLS-Graph v3.00 was used in our analysis.

The measurement model was first assessed followed by the structural model. The strength of the measurement model can be demonstrated by convergent and discriminant validity tests (Hair et al. 1998); that is, items of the same construct being similar and dissimilar from items of other constructs. All reflective constructs in our study exhibited acceptable levels of convergent validity (i.e., in Table 3, Cronbach's Alpha (CA) $>0.7$, Composite Reliability (CR) $>0.7$, and Average Variance Extracted (AVE) $>0.5$ (Fornell and Larcker 1987; Nunnally 1994). The constructs also showed acceptable discriminant validity (i.e., in Table 2 , loadings of all items in factor analysis were above the minimum recommended level of 0.5 and no serious cross-loading $(>0.4)$ was detected). In Table 4, the construct correlations, diagonal elements exceeded other entries in the same row or column (Fornell and Larcker 1987). No multicollinearity problems were detected. Mobilization being a single indicator measure and civic skills being a second-order formative construct were not included in the tests of Tables 2 and 4 .

For formative indicators, where the items represent the causes rather than the effects of the construct, the weights rather than loadings are examined (Table 3 ). Item weights can be interpreted as a beta coefficient in a standard regression. Rather than interpreting the weights in a factor loading sense (i.e., how close the weights are to 1.0), the general approach is to compare the weights of different indicators (Sambamurthy and Chin 1994). In our study, all dimensions of each of the formative constructs (selective outcome incentives, civic skills, and political efficacy) contribute substantially to their respective construct.

Figure 2 and Table 5 present the results of structural model testing with path coefficients estimated by resampling. The results show that collective incentives (H1), selective process incentives ( $\mathrm{H} 2)$, selective outcome incentives ( $\mathrm{H} 3$ ), political efficacy (H4), and civic skills (H5) have significant effects on youths' participation intention in the OPDF. Additionally, connectivity has significant effect on selective process incentives $(\mathrm{H} 7 \mathrm{a})$. The model has adequate explanatory power $\left(\mathrm{R}^{2}=0.45\right)$. 
Table 2. Results of Factor Analysis

\begin{tabular}{|l|c|c|c|c|c|c|c|c|c|}
\hline & \multicolumn{10}{|c|}{ Component } \\
\cline { 2 - 11 } & $\mathbf{1}$ & $\mathbf{2}$ & $\mathbf{3}$ & $\mathbf{4}$ & $\mathbf{5}$ & $\mathbf{6}$ & $\mathbf{7}$ & $\mathbf{8}$ & $\mathbf{9}$ \\
\hline INT1 & 0.17 & 0.26 & 0.17 & -0.02 & 0.16 & 0.16 & 0.05 & 0.16 & $\mathbf{0 . 7 7}$ \\
\hline INT2 & 0.30 & 0.27 & 0.08 & 0.11 & 0.13 & 0.01 & 0.21 & 0.14 & $\mathbf{0 . 7 3}$ \\
\hline COL1 & $\mathbf{0 . 7 3}$ & -0.06 & 0.03 & 0.34 & 0.03 & -0.02 & -0.06 & 0.15 & 0.24 \\
\hline COL3 & $\mathbf{0 . 8 1}$ & -0.11 & 0.10 & 0.21 & 0.10 & 0.06 & 0.07 & 0.08 & 0.16 \\
\hline COL4 & $\mathbf{0 . 8 3}$ & -0.06 & 0.04 & 0.21 & 0.25 & 0.06 & 0.00 & 0.12 & 0.00 \\
\hline COL5 & $\mathbf{0 . 8 2}$ & -0.03 & 0.12 & 0.10 & 0.12 & 0.13 & -0.08 & 0.26 & 0.05 \\
\hline SELP1 & 0.10 & 0.14 & 0.15 & 0.14 & 0.05 & $\mathbf{0 . 7 8}$ & 0.08 & 0.18 & -0.22 \\
\hline SELP2 & 0.07 & 0.09 & 0.14 & 0.25 & 0.20 & $\mathbf{0 . 8 2}$ & 0.11 & -0.11 & 0.17 \\
\hline SELP3 & 0.17 & 0.09 & 0.23 & 0.08 & 0.11 & $\mathbf{0 . 7 1}$ & -0.05 & 0.08 & 0.36 \\
\hline SELD1 & 0.31 & 0.04 & 0.14 & 0.27 & 0.15 & 0.08 & 0.19 & $\mathbf{0 . 8 2}$ & 0.17 \\
\hline SELD2 & 0.29 & 0.07 & 0.17 & 0.23 & 0.18 & 0.08 & 0.16 & $\mathbf{0 . 8 4}$ & 0.16 \\
\hline SELC1 & 0.14 & 0.01 & 0.05 & 0.00 & 0.10 & 0.02 & $\mathbf{0 . 9 3}$ & 0.11 & 0.06 \\
\hline SELC2 & -0.09 & -0.08 & 0.12 & 0.06 & 0.02 & 0.09 & $\mathbf{0 . 9 1}$ & 0.11 & 0.10 \\
\hline IPEF1 & -0.10 & $\mathbf{0 . 7 8}$ & -0.10 & 0.02 & -0.02 & 0.15 & -0.04 & -0.09 & 0.07 \\
\hline IPEF2 & 0.02 & $\mathbf{0 . 8 1}$ & -0.20 & 0.09 & 0.11 & 0.08 & 0.07 & -0.12 & 0.24 \\
\hline IPEF3 & 0.01 & $\mathbf{0 . 8 7}$ & 0.06 & -0.11 & 0.04 & 0.01 & -0.08 & 0.11 & 0.03 \\
\hline IPEF4 & -0.09 & $\mathbf{0 . 8 9}$ & 0.13 & -0.02 & 0.11 & 0.01 & 0.02 & 0.10 & 0.05 \\
\hline IPEF5 & -0.10 & $\mathbf{0 . 9 1}$ & 0.10 & 0.02 & 0.05 & 0.04 & -0.02 & 0.07 & 0.08 \\
\hline EPEF1 & 0.26 & 0.06 & 0.06 & 0.07 & $\mathbf{0 . 8 5}$ & 0.08 & -0.01 & 0.06 & 0.07 \\
\hline EPEF2 & 0.26 & 0.05 & 0.04 & 0.12 & $\mathbf{0 . 8 6}$ & 0.16 & 0.05 & 0.04 & 0.14 \\
\hline EPEF3 & 0.09 & 0.16 & 0.13 & 0.12 & $\mathbf{0 . 8 3}$ & 0.07 & 0.11 & 0.16 & 0.06 \\
\hline CON1 & $\mathbf{0 . 0 6}$ & 0.08 & $\mathbf{0 . 9 0}$ & 0.19 & 0.08 & 0.06 & 0.03 & 0.13 & -0.01 \\
\hline CON2 & 0.13 & 0.07 & $\mathbf{0 . 9 0}$ & 0.21 & 0.02 & 0.14 & 0.09 & 0.03 & 0.04 \\
\hline CON3 & $\mathbf{0 . 1 0}$ & -0.07 & $\mathbf{0 . 8 6}$ & 0.23 & 0.07 & 0.18 & 0.06 & 0.06 & 0.12 \\
\hline CON4 & 0.12 & -0.05 & $\mathbf{0 . 8 9}$ & 0.23 & 0.10 & 0.11 & 0.05 & 0.07 & 0.11 \\
\hline COM1 & 0.17 & 0.06 & 0.28 & $\mathbf{0 . 8 3}$ & 0.06 & 0.11 & -0.03 & 0.07 & 0.07 \\
\hline COM2 & 0.18 & -0.08 & 0.28 & $\mathbf{0 . 8 3}$ & 0.10 & 0.11 & 0.08 & 0.04 & 0.09 \\
\hline COM3 & 0.26 & 0.04 & 0.14 & $\mathbf{0 . 8 1}$ & 0.15 & 0.15 & 0.00 & 0.21 & -0.01 \\
\hline COM4 & 0.23 & -0.04 & $\mathbf{0 . 2 6}$ & $\mathbf{0 . 7 9}$ & 0.08 & 0.12 & 0.05 & 0.14 & -0.05 \\
\hline
\end{tabular}


Table 3. Psychometric Properties of Measures

\begin{tabular}{|c|c|c|c|}
\hline Construct & Item & Weight & Loading \\
\hline \multirow{2}{*}{$\begin{array}{l}\text { Intention (INT) } \\
\mathrm{CA}=0.79, \mathrm{CR}=0.91, \mathrm{AVE}=0.83\end{array}$} & INT1 & \multirow[t]{2}{*}{ N. A. } & $0.90^{* * *}$ \\
\hline & INT2 & & $0.92^{* * *}$ \\
\hline \multirow{5}{*}{$\begin{array}{l}\text { Collective Incentives }(\mathrm{COL}) \\
\mathrm{CA}=0.92, \mathrm{CR}=0.94, \mathrm{AVE}=0.76\end{array}$} & COLI & \multirow[t]{5}{*}{ N. A. } & $0.83^{* * *}$ \\
\hline & COL2 & & $0.88^{* * *}$ \\
\hline & COL3 & & $0.90^{* * *}$ \\
\hline & $\mathrm{COL} 4$ & & $0.88^{* * *}$ \\
\hline & COL5 & & $0.85^{* * *}$ \\
\hline \multirow{3}{*}{$\begin{array}{l}\text { Sel. Process Incentives (SELP) } \\
\mathrm{CA}=0.78, \mathrm{CR}=0.88, \mathrm{AVE}=0.70\end{array}$} & SELP1 & \multirow[t]{3}{*}{ N. A. } & $0.73^{* * *}$ \\
\hline & \begin{tabular}{|l|} 
SELP2 \\
\end{tabular} & & $0.90^{* * *}$ \\
\hline & SELP3 & & $0.88^{* * * *}$ \\
\hline \multirow{6}{*}{$\begin{array}{l}\text { Sel. Outcome Incentives (SELO) } \\
\text { Formative, consisting of } 2 \text { dimensions: } \\
\mathrm{CA}=0.97, \mathrm{CR}=0.99, \mathrm{AVE}=0.98 \\
\text { Political advancement ( } \mathrm{SELC} \text { ) } \\
\mathrm{CA}=0.88, \mathrm{CR}=0.95, \mathrm{AVE}=0.90\end{array}$} & SELD & $0.71^{* * *}$ & \multirow[t]{2}{*}{ N. A. } \\
\hline & \begin{tabular}{|l|} 
SELC \\
\end{tabular} & $0.51^{* * * *}$ & \\
\hline & \begin{tabular}{|l|} 
SELDl \\
\end{tabular} & \multirow[t]{2}{*}{ N. A. } & $0.99^{* * *}$ \\
\hline & SELD2 & & $0.99^{* * *}$ \\
\hline & \begin{tabular}{|l|} 
SELC1 \\
\end{tabular} & \multirow[t]{2}{*}{ N. A. } & $0.94^{* * *}$ \\
\hline & \begin{tabular}{|l|} 
SELC2 \\
\end{tabular} & & $0.95^{* * * *}$ \\
\hline \multirow{18}{*}{$\begin{array}{l}\text { Civic Skill (CIVIC) } \\
\text { Formative, all the items (i.e. individual skill- } \\
\text { acts) are measured with respect to: } \\
\text { Workplace (W.CIV), } \\
\text { Voluntary organizations (V.CIV), and } \\
\text { Religious Institutions (R.CIV) }\end{array}$} & W.CIV & $0.42^{* * * *}$ & \multirow[t]{3}{*}{ N.A. } \\
\hline & \begin{tabular}{|l|} 
V.CIV \\
\end{tabular} & $0.55 * * *$ & \\
\hline & R.CIV & $0.33^{*}$ & \\
\hline & W.CIV1 & $0.44^{*}$ & \multirow[t]{5}{*}{ N. A. } \\
\hline & W.CIV2 & -0.18 & \\
\hline & W.C.IV3 & 0.24 & \\
\hline & \begin{tabular}{|l|} 
W.CIV4 \\
\end{tabular} & 0.32 & \\
\hline & \begin{tabular}{|l} 
W.CIV5 \\
\end{tabular} & $0.34^{*}$ & \\
\hline & V.CIV1 & $0.34 * * *$ & \multirow[t]{5}{*}{ N.A. } \\
\hline & V.CIV2 & -0.02 & \\
\hline & V.CIV3 & $0.42^{* * * *}$ & \\
\hline & V.CIV4 & $0.29^{*}$ & \\
\hline & V.CIV5 & 0.12 & \\
\hline & R.CIV1 & 0.70 & \multirow[t]{5}{*}{ N. A. } \\
\hline & \begin{tabular}{|l|} 
R.CIV2 \\
\end{tabular} & 0.11 & \\
\hline & \begin{tabular}{|l} 
R.CIV 3 \\
\end{tabular} & 0.21 & \\
\hline & R.CIV4 & 0.48 & \\
\hline & R.CIV5 & -0.30 & \\
\hline \multirow{10}{*}{$\begin{array}{l}\text { Political Efficacy (PEF) } \\
\text { Formative, consisting of } 2 \text { dimensions: } \\
\text { Internal political efficacy }(I P E F) \\
C A=0.91, C R=0.94, A V E=0.75 \\
\text { External political efficacy }(E P E F) \\
C A=0.89, C R=0.93, A V E=0.81\end{array}$} & IPEFF & $0.88^{* * *}$ & \multirow[t]{2}{*}{ N. A. } \\
\hline & EPEF & $0.34^{* * * *}$ & \\
\hline & IPEF1 & \multirow[t]{5}{*}{ N. A. } & $0.79^{* * *}$ \\
\hline & IPEF2 & & $0.83^{* * *}$ \\
\hline & IPEF3 & & $0.87^{* * *}$ \\
\hline & IPEF4 & & $0.90 * * *$ \\
\hline & \begin{tabular}{|l|} 
IPEF5 \\
\end{tabular} & & $0.93^{* * *}$ \\
\hline & EPEF1 & \multirow[t]{3}{*}{ N. A. } & $0.90^{* * *}$ \\
\hline & EPEF2 & & $0.92 * * *$ \\
\hline & EPEF3 & & $0.89 * * *$ \\
\hline
\end{tabular}




\begin{tabular}{|c|c|c|c|}
\hline Construct & Item & Weight & Loading \\
\hline \multirow{4}{*}{$\begin{array}{l}\text { Connectivity (CON) } \\
\mathrm{CA}=0.95, \mathrm{CR}=0.97, \mathrm{AVE}=0.88\end{array}$} & CON1 & \multirow[t]{4}{*}{ N.A. } & $0.92 * * *$ \\
\hline & CON2 & & $0.94 * * *$ \\
\hline & CON3 & & $0.94 * * *$ \\
\hline & CON4 & & $0.95 * * *$ \\
\hline \multirow{4}{*}{$\begin{array}{l}\text { Communality (COM) } \\
\mathrm{CA}=0.92, \mathrm{CR}=0.94, \mathrm{AVE}=0.81\end{array}$} & COM1 & \multirow[t]{4}{*}{ N.A. } & $0.90^{* * *}$ \\
\hline & COM2 & & $0.87 * * *$ \\
\hline & COM3 & & $0.92 * * *$ \\
\hline & COM4 & & $0.91^{* * *}$ \\
\hline
\end{tabular}

${ }^{*} \mathrm{p}<0.05 ;{ }^{* *} \mathrm{p}<0.01 ;{ }^{* * *} \mathrm{p}<0.005$

Table 4. Correlations between Constructs

\begin{tabular}{|l|c|c|c|c|c|c|c|c|c|}
\hline & INT & COL & SELP & SELD & SELC & IPEF & EPEF & CON & COM \\
\hline INT & $\mathbf{0 . 9 1}$ & & & & & & & & \\
\hline COL & 0.40 & $\mathbf{0 . 8 7}$ & & & & & & & \\
\hline SELP & 0.36 & 0.31 & $\mathbf{0 . 8 4}$ & & & & & & \\
\hline SELD & 0.45 & 0.52 & 0.30 & $\mathbf{0 . 9 9}$ & & & & & \\
\hline SELC & 0.24 & 0.11 & 0.16 & 0.32 & $\mathbf{0 . 9 5}$ & & & & \\
\hline IPEF & 0.37 & -0.10 & 0.21 & 0.09 & -0.20 & $\mathbf{0 . 8 7}$ & & & \\
\hline EPEF & 0.37 & 0.43 & 0.36 & 0.40 & 0.16 & 0.18 & $\mathbf{0 . 9 0}$ & & \\
\hline CON & 0.27 & 0.29 & 0.40 & 0.35 & 0.18 & 0.02 & 0.24 & $\mathbf{0 . 9 4}$ & \\
\hline COM & 0.23 & 0.49 & 0.40 & 0.48 & 0.12 & 0.01 & 0.32 & 0.51 & $\mathbf{0 . 9 0}$ \\
\hline
\end{tabular}

Table 5. Results of Hypothesis Tests

\begin{tabular}{|l|c|c|c|}
\hline \multicolumn{1}{|c|}{ Hypothesis } & Coefficient & T-value & Outcome \\
\hline H1: COL to INT & 0.27 & $3.08^{* * *}$ & Supported \\
\hline H2: SELP to INT & 0.13 & $1.70^{*}$ & Supported \\
\hline H3: SELO to INT & 0.25 & $2.81^{* * *}$ & Supported \\
\hline H4: PEF to INT & 0.32 & $4.24^{* * *}$ & Supported \\
\hline H5: CIV to INT & 0.16 & $2.44^{* *}$ & Supported \\
\hline H6: MOB to INT & 0.04 & 0.62 & Not supported \\
\hline H7a: CON to SELP & 0.40 & $4.65^{* * *}$ & Supported \\
\hline H7b: CON to INT & 0.11 & 1.21 & Not supported \\
\hline H8: COM to INT & -0.15 & $1.73^{*}$ & Not supported \\
\hline
\end{tabular}

$*_{p}<0.05 ; * * p<0.01 ; * * p<0.005$.

$\dagger$ Significant but in opposite direction 


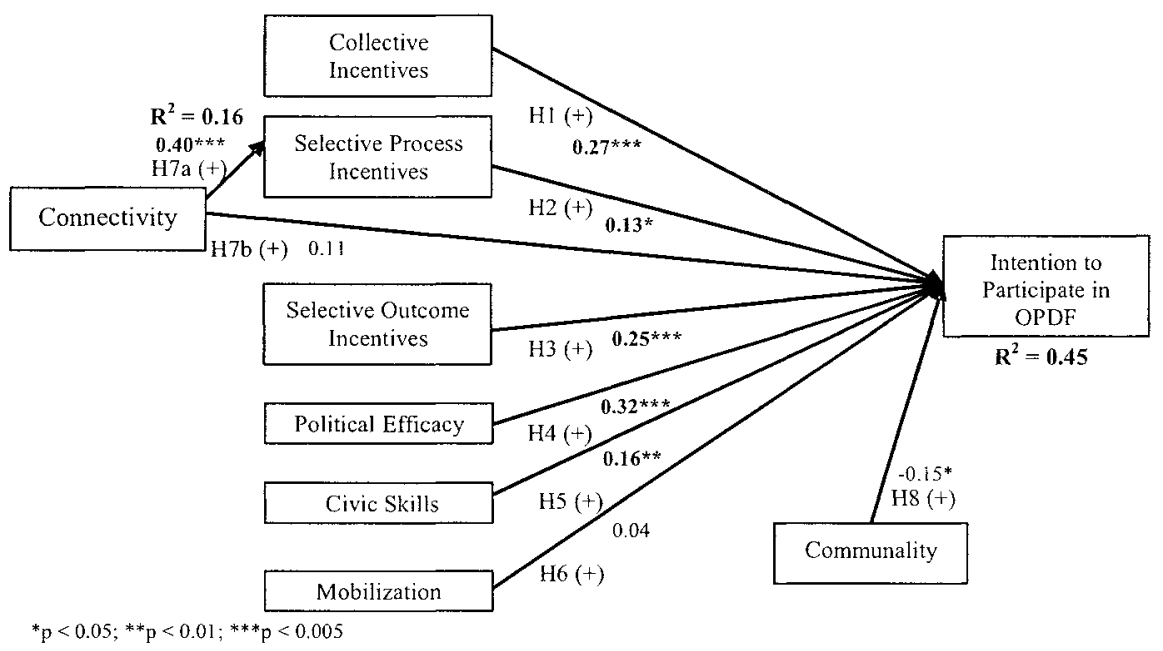

Figure 2. Graphical Summary of Results

\section{DISCUSSION, IMPLICATIONS AND CONCLUSION}

In a preliminary effort that attempts to integrate relevant work from political science and IS fields in explaining a youths' participation in OPDF, our study shows that existing offline participation theories may be applicable in the electronic context. Additionally, our findings also suggest that ICT can have both positive and negative impacts on a youths' e-participation intention. All motivational factors hypothesized have significant effects on youths' intention to participate in OPDF. Youths' eparticipation intention is driven by the collective incentives that can also be enjoyed by nonparticipants and selective incentives derived from both the process and outcomes of participation. Accordingly, e-participation practitioners may convey to youths the potential benefits that can be brought about by the initiative to the broader society. Additionally, efforts can to be invested to make the participation process in OPDF more enjoyable through such means as having moderators to improve the interactivity of discussion (see Edwards 2002). Explicit appreciation of youths' fulfillment of civic duty may be communicated to them, so as to reinforce their emphasis on such incentives. Online networking opportunities can also be provided to youths who are looking to advance their political career by involving prominent political figures from the community in the discussion.

Apart from incentives, civic skills are a significant resource factor that can determine a youths' participation intention. This indicates that youths' lack of abilities to articulate their ideas and to involve in discourse with others may be an important barrier to their participation. Mobilization is not significant in this study probably because there were only a handful of respondents who had received requests from others to participate 
in the OPDF. Future research may examine the effect of mobilization further by investigating what forms of social influences may motivate youths to participate. Both internal and external political efficacies are found to be significant determinants of youths' participation intention. This implies that both beliefs in personal political competence and government's responsiveness can increase participation. With respect to these findings, opportunities need to be provided for youths to practice and develop skills and knowledge that can help them in participation. This may be achieved through education and by creating supportive political institutions (Rubenson 2000) that encourage the formation of voluntary organizations (e.g., study circles). Since awareness about avenues for e-participation appears to be low in our study, government needs to put additional effort into publicizing these channels such as the consultation portal.

Regarding the hypotheses related to ICT features, connectivity is found to significantly influence selective process incentives but not youths' participation intention. This shows that the effect of connectivity on youths' participation intention is mediated by the selective process incentives. Interestingly, communality was found to be a negative significant determinant of intention. A possible explanation for this finding is from the perspective of collective effort model (Karau and Williams 1993). The model posits that people will contribute more to the collective effort if they perceive that their inputs are unique and important, and vice versa. In this light, communality may instead deter individuals' intention to participate because they are uncertain of the uniqueness and importance of their ideas since the policy issue may have been well deliberated by others with the ease of information exchange. The dual impacts of ICT on participation raises the caution that while ICT can in theory provide promising opportunities for enhancing participation, ICT deployment for this purpose needs to be done cautiously. E-participation practitioners can strive to enhance connectivity by designing a forum that offers easy correspondence between two or more participants. For communality, practitioners may attempt to minimize its negative impact while retaining its benefits by employing a forum moderator. The moderator may summarize the discussion and identify the important and unique points covered periodically, so potential participants get an idea of whether their inputs are still valuable and subsequently make the decision to participate (see Edwards 2002).

As an initial attempt to explore the antecedents of youths' participation in OPDF, several limitations need to be recognized when interpreting the results of this study. First, the study was conducted in a single nation. Rubenson (2000) has highlighted the importance of political institutions (e.g., government supportive of civic group formation) in accounting for participation. Future research may be conducted in other countries with different political institutions to further validate our results. Second, the sample was confined to university students. Although studies have shown that factors pertinent to participation of other youths are not substantially different (Jarvis et al. 2005), a validation can be done to verify these results. Third, the sample size can be increased in future studies to obtain better statistical power. Additionally, actual participation behavior of youths can be measured in future studies (although support has been found for intention as a predictor of actual behavior, e.g., Taylor and Todd 1995). Future studies may examine youths' e-participation with respect to issues of a different nature from the current study (e.g., controversial issues with divided views). Individuals may perceive issues as having different importance or salience to them that subsequently influence their participation intention (Nadeau et al. 1995). Since the model has been 
developed for citizens in general, it can also be used to investigate the differences between youth and other groups. Further, differences between OPDF and other eparticipation mechanisms can be studied. Finally, interviews with subjects can be used to supplement the survey questionnaire to obtain better understanding of individuals' eparticipation behavior.

As governments around the globe attempt to leverage the potential of e-participation initiatives, studies of this nature can serve to inform theory and practice on how ICT can be employed to enhance citizen participation in democratic processes. Specifically, they may add to the understanding of an important issue facing countries around the world: how inclusion of youths in democratic processes can be promoted to prepare them for future governance.

\section{References}

Aldrich, J. H. "National Choice and Turnout," American Journal of Political Science (37), 1993, pp. 246-278.

Aristotle. Politics, London: Penguin Classics, 1987.

Bennett, S. E. "Why Young Americans Hate Politics, and What We Should Do to About it," Political Science and Politics (30:1), 1997, pp. 47-53.

Brady, H. E., Verba, S., and Schlozman, K. L. "Beyond SES: A Resource Model of Political Participation," American Political Science Review (89:2), 1995, pp. 271-294.

Campbell, A., Gurin, G., and Milner, W. The Voter Decides, Evanston, IL: Row Peterson and Company, 1954.

Chia, S-A. "Public Views Now a Must for All Policies," The Straits Times (Singapore), Prime News, November 13, 2004.

Clary, E., Ridge, R., Stukas, A., Snyder, M., Copeland, J., Haugen, J., and Miene, P. "Understanding and Assessing the Motivations of Volunteers: A Functional Approach," Journal of Personality and Social Psychology (74:6), 1998, pp. 1516-1530.

Cook, K. S. "The Microfoundations of Social Structure: An Exchange Perspective," in J. Huber (ed.), Macro-Micro Linkages in Sociology, Newbury Park, CA: Sage Publicatoins, 1991, pp. $29-45$.

Craig, S. C., Niemi, R. G., and Silver, G. E. "Political Efficacy and Trust: A Report on the NES Pilot Study Items," Political Behavior (12:3), 1990, pp. 289-314.

Day, D. "Citizen Participation in the Planning Process: An Essentially Contested Concept?," Journal of Planning Literature (11:3), 1997, pp. 421-434.

Edwards, A. R. "The Moderator as an Emerging Democratic Intermediary: The Role of the Moderator in Internet Discussion about Public Issues," Information Polity (7), 2002, pp. 3-20.

Fornell, C. A Second Generation of Multivariate Analysis: Methods (Volume 1), New York: Praeger, 1982.

Fornell, C., and Larcker, D. "Evaluating Structural Equation Models with Unobservable Variables and Measurement Error," Journal of Marketing Research (18), 1987, pp. 39-50.

Fulk, J., Flanagin, A. J., Kalman, M. E., Monge, P. R., and Ryan, T. "Connective and Communal Public Goods in Interactive Communication Systems," Communication Theory (6:1), 1996, pp. 60-87.

Gamson, W. A. The Strategy of Social Protest, Homewood, IL: Dorsey, 1975.

Hair, J. F., Anderson, R. E., Tatham, R. L., and Black, W. C. Multivariate Data Analysis with Readings ( $5^{\text {th }}$ ed.), New York: Macmillan, 1998. 
Hiltz, S. R., and Turoff, M. The Network Nation: Human Communication via Computer, Cambridge, MA: MIT Press, 1978.

Institute of Politics. "The Institute of Politics Survey of Student Attitudes: A National Survey of College Undergraduates," John F. Kennedy School of Government, Harvard University, 2002 (available online at http://www.iop.harvard.edu/pdfs/survey/2002.pdf).

Irvin, R. A., and Stansbury, J. "Citizen Participation in Decision Making: Is it Worth the Effort?," Public Administration Review (64:1), 2004, pp. 55-65.

Jarvis, S. E., Montoya, L., and Mulvoy, E. "The Political Participation of Working Youth and College Students," Circle Working Paper (36), August 2005 (available online at http://www.civicyouth.org/PopUps/WorkingPapers/WP36Jarvis.pdf).

Karau, S., and Williams, K. "Social Loafing: A Meta-Analytic Review and Theoretical Integration," Journal of Personality and Social Psychology (65:4), 1993, pp. 681-706.

Kumar, N., and Benbasat, I. "Para-Social Presence and Communication Capabilities of a Web Site," e-Service Journal (1:3), 2001, pp. 5-25.

Kumar, N., and Vragov, R. "The Citizen Participation Continuum: Where Does the US Stand?," in Proceedings of the $11^{\text {th }}$ America's Conference on Information Systems, Omaha, NE, August 11-14, 2005, pp. 1984-1990.

Lyons, W., and Alexander, R. "A Tale of Two Electorates: Generational Replacement and the Decline of Voting in Presidential Elections," Journal of Politics (62), 2000, pp. 1014-1034.

Monge, P., Fulk, J., Kalman, M., Flanagin, A., Parnassa, C., and Rumsey, S. "Production of Collective Action in Alliance-Based Interorganizational Communication and Information Systems," Organization Science (9:3), 1998, pp. 411-433.

Moore, G. C., and Benbasat, I. "Development of an Instrument to Measure Perceptions of Adopting an Information Technology Innovation," Information Systems Research (2:3), 1991, pp. 192-222.

Nadeau, R., Niemi, R. G., and Amato, T. "Emotions, Issue Importance, and Political Learning," American Journal of Political Science 39(3), 1995, pp. 558-574.

Niemi, R. G., Craig, S. C., and Mattei, F. "Measuring Internal Political Efficacy in the 1988 National Election Study," American Political Science Review (85:4), 1991, pp. 1407-1413.

Nunnally, J. Psychometric Theory ( $3^{\text {rd }}$ ed.), New York: McGraw-Hill Education, 1994.

Olson, M. The Logic of Collective Action: Public Goods and the Theory of Groups, Cambridge, MA: Harvard University Press, 1965.

Parry, G., Moyser, G., and Day, N. Political Participation and Democracy in Britain, New York: Cambridge University Press, 1992.

Pattie, C., Seyd, P., and Whiteley, P. "Citizen and Civic Engagement: Attitudes and Behavior in Britain," Political Studies (51), 2003, pp. 443-468.

Pew Research Center. "Internet Sapping Broadcast News Audience," June 11, 2000 (available online at http://www.people-press.org/reports/display.php3?ReportlD=36).

Rosenstone, S. J., and Hansen, J. M. Mobilization, Participation, and Democracy in America, New York: MacMillan, 1993.

Rubenson, D. "Participation and Politics: Social Capital, Civic Voluntarism, and Institutional Context," paper presented at the Political Studies Association-UK $50^{\text {th }}$ Annual Conference, London, April 10-13, 2000.

Sambamurthy, V., and Chin, W. W. "The Effects of Group Attitudes Toward Alternative GDSS Designs on the Decision-Making Performance of Computer-Supported Groups," Decision Science (25: 2), 1994, pp. 215-41.

Scholzman, K., Verba, S., and Brady. H. "Participation's Not a Paradox: The View from American Activists," British Journal of Political Science (25), 1995, pp. 1-36. 
Seyd, P., and Whiteley, P. Labor Grass Roots: The Politics of Party Membership, Oxford, UK: Clarendon Press, 1992.

Seyd, P., Whiteley, P., and Pattie, C. "Citizenship in Britain: Attitudes and Behavior," The Political Quarterly (72:1), 2001, pp. 141-148.

Taylor, S., and Todd, P. A. "Understanding Information Technology Usage: A Test of Competing Models," Information Systems Research (6:2), 1995, pp. 144-176

Thrane, L. E., Shelley II, M. C., Shulman, S. W., Beisser, S. R., and Larson, T. B. "E-Political Involvement: Age Effects or Attitudinal Barriers?,"Journal of E-Government (1:4), 2004 , pp. 21-37.

UNPAN. UN Global E-Government Readiness Report, United Nations, 2005, (available online at http://www.unpan.org/egovernment5.asp).

Verba, S., and Nie, N. Participation in America: Political Democracy and Social Equality, New York: Harper and Row, 1972.

Verba, S., Schlozman, K, and Brady, H. Voice and Equality: Civic Voluntarism in American Politics, Cambridge, MA: Harvard University Press, 1995.

Vinluan, G., Teo, A., Seah, V., Grewal, H., and Sidek, I. (eds.), Quarterly Newsletter of the Feedback Unit, January 2005 (available online at http://www.gov.sg/).

Whiteley, P. "National Choice and Political Participation-Evaluating the Debate," Political Research Quarterly (48), 1995, pp. 211-234.

Whyte, A., and Macintosh, A. "Analysis and Evaluation of E-Consultations," e-Service Journal (2:1), 2002, pp. 9-34.

\section{About the Authors}

Chee Wei Phang is currently a doctoral student in the Department of Information Systems, School of Computing, at the National University of Singapore. His research interests include eGovernment, eParticipation, IT-induced organizational change, IT innovation adoption, and knowledge management. His work has been published or is forthcoming in IEEE Transactions on Engineering Management and top-tier information systems conferences such as the International Conference on Information Systems, the European Conference on Information Systems, the Hawaii International Conference on System Sciences, and the Americas Conference on Information Systems. He is a member of the Association for Information Systems. Phang can be reached at phangcw@comp.nus.edu.sg.

Atreyi Kankanhalli is an assistant professor in the Department of Information Systems, School of Computing, at the National University of Singapore. She received her Ph.D. in information systems for the National University of Singapore. Atreyi has been a visiting scholar at the Haas Business School, University of California, Berkeley, and the Indian Institute of Science, Bangalore. Prior to joining NUS, she had considerable experience in industrial research and development, and has consulted for a number of organizations including the World Bank. Atreyi's work has been published in journals such as MIS Quarterly, Journal of the American Society of Information Science and Technology, Communications of the ACM, Decision Support Systems, and International Journal of Information Management. She has presented research at conferences including the International Conference on Information Systems, the Hawaii International Conference on System Sciences, and the Workshop on Information Technologies and Systems. She has served or is serving on several IS conference committees such as PACIS, ICKM, and IRMA and on the editorial boards of International Journal of Knowledge Management, Journal of Global Information Management, and Journal of Information Privacy and Security. Her research interests include knowledge management, eGovernment, virtual teams, and information systems security. Atreyi can be reached at atreyi@comp.nus.edu.sg. 